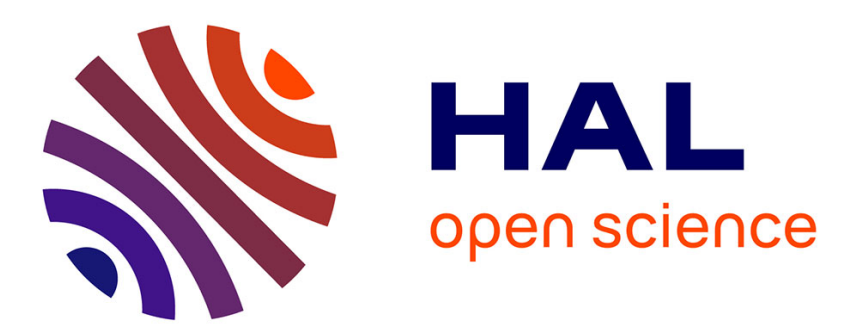

\title{
Water governance across competing scales: coupling land and water management
}

\author{
K.A. Daniell, O. Barreteau
}

\section{To cite this version:}

K.A. Daniell, O. Barreteau. Water governance across competing scales: coupling land and water management. Journal of Hydrology, 2014, 519, pp.2367-2380. 10.1016/j.jhydrol.2014.10.055 . hal01122042

\section{HAL Id: hal-01122042 \\ https://hal.science/hal-01122042}

Submitted on 3 Mar 2015

HAL is a multi-disciplinary open access archive for the deposit and dissemination of scientific research documents, whether they are published or not. The documents may come from teaching and research institutions in France or abroad, or from public or private research centers.
L'archive ouverte pluridisciplinaire HAL, est destinée au dépôt et à la diffusion de documents scientifiques de niveau recherche, publiés ou non, émanant des établissements d'enseignement et de recherche français ou étrangers, des laboratoires publics ou privés. 


\title{
Water governance across competing scales: coupling land and water management
}

\author{
Journal of Hydrology Special Issue
}

Katherine A. Daniell (Australian National University) and Olivier Barreteau (IRSTEA, UMR G-EAU, France)

\section{Abstract}

Water governance is a complex process to manage and improve due to the large numbers of competing scales and levels inherent within it. Effectively supporting any water governance process does not just rely on hydrological knowledge of a water system, but much broader trans-disciplinary understanding of a whole socialhydrological system. In this paper we show how there are commonly up to eight or more competing scalesspatial, temporal, administrative, institutional, management, network, knowledge/information and stakes/issues - present in any water governance situation. Processes in one scale can then create flows or externalities that produce multi-level, cross-scale or rescaling effects. A typology of six types of externalities or flows is provided-physical or material flows (e.g. water and solute movement), information and knowledge, political and social control, financial flows, human flows, and an irreversibility effect (e.g. flows, such as that of time passing, which lead to cumulative effects that are difficult or impossible to reverse)-and used to study the examples provided in the 15 papers of this special issue. From these insights, conclusions are drawn on how conflicts across competing scales are currently being managed, the mechanisms involved in bridging scales, and to what extent currently privileged scales and/or governance structures are appropriate for effectively managing water and land. The two general trends observed for multi-level and cross-scale management remain the need for collaborative governance processes and facilitators of these interactions, as well as the development of savvy coalitions for water governance change who understand and can effectively navigate these complex multi-level and multi-scalar systems. There is also a need to recognise that water basins or watersheds are social constructions and not always the most effective arenas for water governance. Problemsheds based on concepts such as the French "territoire" (territory), may in fact prove more pertinent in many cases (e.g. highly engineered systems) due to the unequivocal social nature of their construction and ability to delineate a range of agreed upon social-hydrological systems for management. 


\section{Key words}

Water governance, cross-scale, multi-level, rescaling, externalities, conflict

\section{INTRODUCTION}

Water governance is becoming an increasingly important area of study for hydrologists, as the impacts of human decisions on water flows and their various management scales are recognised. Hydrology has long tackled issues of water flow and quality across basins - from rain to soil and sub-soil, from upstream to downstream, between surface water and groundwater systems, and through interlinked watersheds-with the understanding that these stocks and flows can be modified en-route due to the actions of people, including through organised water management and governance processes. In this setting, one common aim of water governance is to develop management processes and infrastructure systems that can control hydrological variability at different levels of spatial and temporal scales. For example, water storages, distribution systems and drainage networks are developed for long-term seasonal and inter-decadal variability-in the case of large dams and irrigation systems-as well as shorter-term variability, such as flooding events, that may take place over hours (e.g. urban flash floods), days (e.g. catchment-based river flooding) or months (e.g. basin-wide flood-plain inundation events). Particularly when looking at water supply issues, water allocation rules are elaborated and negotiated in order to provide water to people when and where they most need it, rather than when and where it would naturally be available.

Such decisions on water governance systems have an impact on the capacity of people and institutions to make autonomous decisions about water and land management, both within basins and in their interlinked socialecological systems: what we will term in this paper the governance of "social-hydrological systems". Water governance affects, and is equally affected by, decision processes in a variety of other areas such as crop selection, land use policies, energy systems and environmental management. In other words, there is a range of externalities created by decisions and actions that may lead to problems for other people at different levels or scales in the governance system. Possible conflicts between the aforementioned decision areas are typically handled at a range of administrative and institutional scales (linked to geographical regions), which often do not fit watershed or groundwater reserve boundaries. Conflicts can also occur between jurisdictions and a range of 
interests (public and/or private), leading some hydrology academics to suggest that analysing management of "problem-sheds" may be more relevant than management of "water-sheds" to improve water governance systems.

Trade-offs have to be made between these competing scales in governance processes in order to reach decisions that are mutually beneficial for water and land management, and the people responsible for them. Yet, within decision processes, individuals and groups play major roles in constructing which scales are considered to be important, embedding their own views, knowledge and values within these preferred representations. Some act to bridge scales (e.g. knowledge brokers, boundary organisations) while others act to design and reinforce existing boundaries and scales of governance. Facilitation and coordination across competing or interlinked scales occur through both formal and informal institutions, as well as via different types of socio-technical infrastructure which include sets of rules, thresholds, indicators, models and information systems.

In this paper, we propose that many water governance challenges require multi-level, cross-scale governance processes and conflict resolution. To make this argument, we draw on the evidence of a range of papers included in this special issue, that have considered questions such as:

- How are conflicts across competing scales managed?

- What mechanisms are involved in bridging scales?

- To what extent are currently privileged scales and/or governance structures appropriate for effectively managing water? And what might be more appropriate, for example, to cope with changing regional climate and demand patterns?

Before discussing these issues and the insights from the papers, we consider it first important to define and formalise what we mean by "scale or level" and "cross-scale or multi-level" and describe a number of scales relevant to the study of water governance. We then propose a typology of externalities that can be produced at one level on a scale and the potential multi-level or cross-scale that can result. We then use this typology to describe how water governance situations can be altered by specific actions and discuss the above questions, 
Author-produced version of the article published in Journal of Hydrology, 2014, N 519 , p. 2367-2380

The original publication is available at http://www.sciencedirect.com

http://dx.doi.org/10.1016/j.jhydrol.2014.10.055

including governance mechanisms and institutions that can be used for better managing land and water conflicts across competing scales. We conclude with perspectives for future water governance practice and research.

\section{DEFINITIONS AND SCALE DESCRIPTIONS}

\subsection{Scales and levels of organisation}

Scale is a commonly used word in many disciplines, including hydrology, as well as in daily language. It is therefore subject to frequent use without exact definition, which leads to it being used with different meanings and makes scholarship on scale issues challenging. In the water sector, there is a constant confusion between scale and levels of organization. We should be rigorous on these definitions, although we note that multiple definitions that do not match those below are possible (Sayre, 2005). Firstly, levels can be considered as an extension of scale as a graduated range. Values constituting a whole range defining a scale can be defined within a continuous set, or a non-continuous one. The whole range is then a set of classes, which are also named "levels" or "levels of organization". In the field of governance, both organisation levels and scales have been used increasingly interchangeably, leading to some confusion. In this paper, we will use the term "scale" when dealing with a graduated range of extent, and levels of organisation when dealing with non-continuous classes. For more in-depth discussion on these terms and more, see Gibson et al. (2000).

However, it is also important to acknowledge a second definition of scale from the Oxford Dictionary as "The relative size or extent of something" as this will be important when we discuss some of the authors' papers, especially when issues of the subjective construction of scale, or "re-scaling", processes come up.

Taking the first measurement definition, we consider that for each scale (e.g. temporal, spatial) a number of "levels" can be defined. For example, a temporal scale may include the levels of hours, days, weeks, years, centuries etc. (i.e. different lengths of time) or a spatial scale may include the levels of ecosystem patch, catchment, river-basin or eco-region, and biome (i.e. different area sizes of geographical space). Expanding on the scale and level descriptions provided in Cash (2006), in Figure 1 we provide a number of scales that are relevant to questions of water governance with example levels. Each one of these different scales and its relevance to water governance challenges is then briefly described with reference to the literature. We note that each scale category is independent of others but may commonly be combined with others. For example, an 
administrative scale and spatial scale are commonly found together, as an administration at any level also typically has jurisdiction over a set spatial area or level. The list of scales is not comprehensive, as other scales could also be constructed for other purposes.

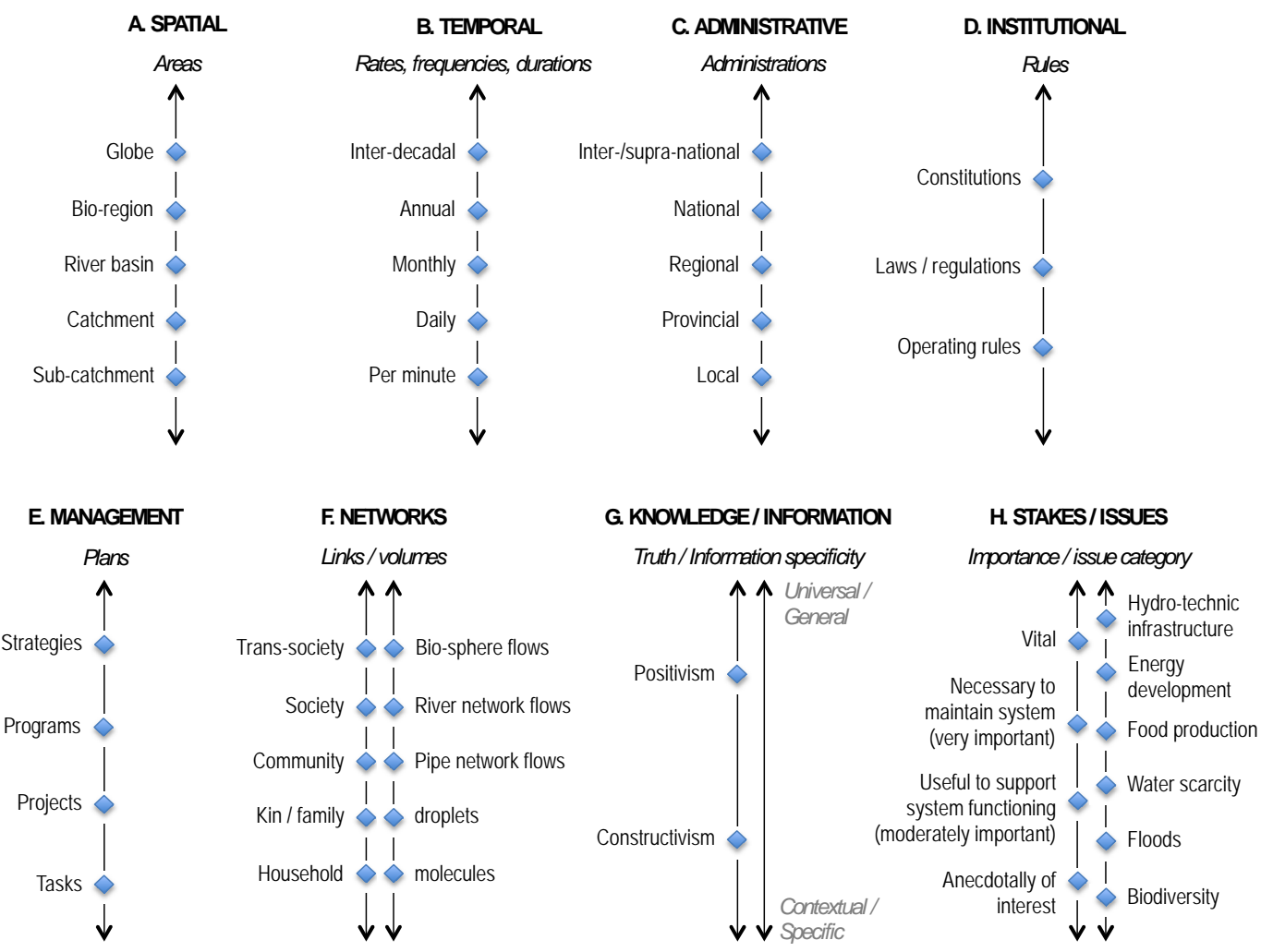

<INSERT FIGURE 1 HERE>

Figure 1: Representation of scales and internal levels relevant to water governance. Expanded and adapted from Cash (2006)

Following these individual scale descriptions, we also reflect on the issues of multi-level and cross-scale interactions and the processes of scale construction and rescaling.

\subsection{Dimensions of grading}

Processes related to hydrology and water governance can be described according to the entities they use and/or modify. The state of these entities is described according to various dimensions, along which they are situated. We list these various possible dimensions below. 
Author-produced version of the article published in Journal of Hydrology, 2014, N 519 , p. 2367-2380

The original publication is available at http://www.sciencedirect.com

http://dx.doi.org/10.1016/j.jhydrol.2014.10.055

\subsubsection{Spatial scale}

Space is one of the most common dimensions, along with time (discussed next), that is most commonly considered in hydrological studies and water governance more generally (e.g. Klemes, 1983; Bergstrom, 1998; Sivapalan et al., 2004; Merz et al., 2009; Syme et al., 2012). Understanding the spatial scale, and how processes at different levels on it interact, has also been a major focus of other related disciplines such as ecology (e.g. Levin, 1992; Peterson and Parker, 1996), sustainability studies (e.g. Dovers, 2004); geography (e.g. Harvey, 1969; Meentemeyer, 1989; Turner et al., 1989), sociology (e.g. Tilly, 1984; Coleman, 1990) and environmental politics or political ecology (e.g. Swyngedouw, 1997; Brenner, 2001), and to a lesser extent in economics (e.g. Veldkamp et al., 2011). For water governance and hydrology, the spatial scale can be divided into a range of different series of levels based on typography or other definitions of areas (e.g. watersheds/ecosystems; administrative areas (see also 2.3); areas of flow-dynamics-from the micro molecular level to the macro flood-plain flow level). There are also strong debates in and across disciplines about the importance and existence of specific spatial levels, depending on epistemological and ontological positioning, about the extent to which certain levels "exist" such as the topological definition of a river basin, or are socially constructed (e.g. Swyngedouw, 2004) such as the extent of an urban area's catchment which will depend on the social definition of what is considered to be "urban" as an example (see Sayre, 2005, for further discussion).

\subsubsection{Temporal scale}

Time is another vital dimension considered in hydrological studies, but perhaps more implicitly considered in some of the water governance literature. The resolution or level of temporal data (e.g. minutes, hours, days, months, years) used for hydrological studies will permit different understandings of phenomena such as flash floods, rain-water tank storage levels, riverine and basin flooding, droughts and climate change patterns on rainfall and runoff. Water governance mechanisms, planning regimes and institutions may also be specifically designed to manage these phenomena and others, linking them explicitly to different levels of the temporal scale through the study of rates, durations and frequencies. There are some authors who study water-related phenomena explicitly across the temporal scale, such as Carpenter and Kitchell (1987) who investigated the influences of temporal scale variance in limnetic primary production (ecological productivity of lakes and associated food webs). Issues of temporal scale are also closely attached to spatial scale in much ecological work 
Author-produced version of the article published in Journal of Hydrology, 2014, N 519 , p. 2367-2380

The original publication is available at http://www.sciencedirect.com

http://dx.doi.org/10.1016/j.jhydrol.2014.10.055

(as discussed in Section 2.2.1) or in studies of spatio-temporal variability in areas such as soil science and

agricultural water use (e.g. Starr, 2005). Issues of temporal scales also feature prominently in some economics-

based works (e.g. Dasgupta, 1997; Daly, 1992), which is of particular interest to water governance regimes which include water markets and pricing designed to support water management, use efficiency and security under specific temporalities. Two such major economics issues include: the irreversibility effect for decisions under uncertainty (Henry, 1974); and the computing of "depreciation costs", important for renewable resources management, that can make financing infrastructure development appear to be more or less economically viable. In particular, the choice of discount rate in these calculations is very sensitive to rather ad hoc choices related to the long term (Carey and Zilberman, 2002). Decisions on infrastructure or land use taken as a consequence are then non-reversible and may generate adverse effects such as agricultural land losses (Hodge, 1984). Finally, in water governance, time dimension issues and mismatches also arise linked to short-term political agendas versus longer-term water planning and sustainable development needs (see also Cumming et al., 2006).

\subsubsection{Administrative or jurisdictional (legal) scale}

The administrative or jurisdictional scale is concerned with administrations, such as governments or governing organisations, and the levels that they are set up at such as the local, provincial, regional, national or supranational level. Administrations or political units at each of these levels are thus typically linked to a specific geographical level or area where they hold jurisdiction. The administrative scale is one of the most common scales evoked in the water governance literature, or the political sciences literature more broadly, with much debate over how water management administrations would be more appropriately created at the basin or catchment level, rather than being based on most existing jurisdictional boundaries that are not topologically or hydrological system-based. This is the kind of mismatch or issue of "fit" studied by authors such as Ostrom et al. (1961), Young (2002a), Cumming et al. (2006) or Moss and Newig (2010) where jurisdictional (territorial) boundaries of governing bodies do not match the extent of the (often public) goods and resources requiring management by the administration to achieve their goals. Other forms of governance in the literature, including mono-centric governance, multi-level governance or adaptive governance, make different assumptions about 
the levels and interactions needed on the administrative scale for effective management of human-environment problems such as those of water and land management (Termeer et al., 2010).

\subsubsection{Institutional scale}

The institutional scale, which is typically closely linked to administrative and spatial scales, is concerned with rules. The levels of rules on this scale could range from constitutions, to laws and policies, to operating rules. This scale is one that is thus commonly evoked in both water governance literature and practice. However, the title "institutional scale" is rarely directly evoked in the water governance literature, despite the fact that all studies of water law, policy or development of rules for managing water take it implicitly as a key dimension of importance in their work. Specifically, this scale is a central interest of legal practitioners and institutional economists (e.g. Ostrom et al., 1961; 1994; Esty, 2006) and those dealing with other operating rules such as those of markets (e.g. Samuelson, 1973; Krugman, 1986) or water infrastructure, allocation and valuation issues (e.g. Dinar et al., 1997; De Blaeij et al., 2011; Foerster, 2011). Ostrom's (1994) work on the Institutional Analysis and Development (IAD) framework is perhaps the work that most explicitly treats this scale and the importance of considering its different levels, although see also Cash (2006).

\subsubsection{Management scale}

The management scale concentrates specifically on plans. The levels of this scale then correspond to the extent or specificity of the planning activity. This, for example, can range from tasks at a lower level, to projects and programs at a mid-level and strategies at a higher level. At this higher level, there may be significant overlap with the institutional scale level of "laws and policies" depending on the focus of the policies. This management scale may find itself embedded in any of the administrative and spatial levels with tasks, projects and strategies being designed for different water governance-related spatial territories and administrations. Despite its importance for the operationalization of good water governance, like the "institutional scale", the "management scale" rarely receives explicit mention but is implicitly evident in many water governance documents. For example, the Quebec province water policy in Canada speaks about the development of more effective "policies, programs and projects of various kinds" (Gouvernement du Québec 2002, p.17) and the alignment of other scales, as discussed in Cohen (2011). Likewise, the "good governance" report (Ackmouch, 2011) for the most 
recent World Water Forum (2012) in Marseille, France, makes reference to high level strategies to encourage integrated water resources management, as well as river basin management plans and activities within them, highlighting the importance of coupling such management initiatives with measurable targets and indicators to assess progress against different management objectives required for good water governance. Much more information on this scale and the levels of definition within it is evident in the management and planning literature (e.g. Ansoff, 1984; Mintzberg, 1989; Dandy et al., 2007).

\subsubsection{Network scale}

The network scale focusses on linkages. In the case of water governance, the levels of linkages (or volume thereof) may define a variety of phenomena. For example, on the social side from individual, family, kin/community to society and trans-society (e.g. Cash, 2006) or on the physical water side from a collection of water molecules (relevant for nano-filtration or other molecular level processes) to water droplets, small volumes of water flow, up to larger water flows in distribution networks and flood-waters. Volumes of production of goods, such as agricultural produce, could also constitute levels on such a "network scale" and hence are often used in the study of economics (e.g. Fuss and McFadden, 1978). Again, this scale is not so commonly explicitly evoked in the water governance literature, but there are increasing numbers of studies taking place on the importance of networks of different sizes for adaptive or network governance (e.g. Rhodes, 1996), including specifically related to water (e.g. Lowry et al., 2009; Garmestani and Benson, 2013). Studies of different sized water flow networks, both constructed (pipes and canals) and more natural (streams and rivers), is a foundation of water engineering and hydrology, so also commonly forms a basis for water governance practice.

\subsubsection{Knowledge and information scales}

Knowledge and information scales focus on the type of "truth" or specificity of information. They may be constructed to present levels ranging from specific or contextual to general and universal, which could be relevant to the development of knowledge for informing water governance practice at multiple spatial, administrative or institutional levels. Scales could equally be developed to categorise ways of knowing or epistemologies, from a truth that is "out there to be discovered/refuted" (e.g. positivism) to one that is 
Author-produced version of the article published in Journal of Hydrology, 2014, N 519 , p. 2367-2380

The original publication is available at http://www.sciencedirect.com

http://dx.doi.org/10.1016/j.jhydrol.2014.10.055

completely socially constructed (e.g. constructivism). More in-depth reflections on such scale issues are present in Dovers (2004), Manson (2008) and Buizer et al. (2011), including on the relationships between epistemology and scale construction itself. Such competing ways of understanding the world commonly result in conflicts in water management and governance research, so thinking about these differences and competition between them as a scale issue to consider may prove useful. Likewise, scales constructed around water information (not previously included in other scale categories) are also relevant to water governance such as one from personal/household water use preferences to neighbourhood, city and regional preferences.

\subsubsection{Stake and issues scales}

Scales based on categories of stakes and issues ("enjeux" in French) focus on the type of importance certain actors may place on resources, or use to categorise types of stakes and/or issues. For example, the first type of stake and issues scale focussing on importance may present levels from "anecdotally of interest" to "vital". Such scales could also match, for example, the definition of a scale of "salience" as defined and used by Frohlich and Oppenheimer, cited in Ostrom (2005, p.107), where salience is "the degree to which an element is linked to possible changes in the welfare of the decision maker" (or in our case any "actor" or "stakeholder"). The second type of stake and issues scale then looks at categories, or possibly sectors, of types of stakes and issues In the water governance domain; these could range from "natural" to "man-made" or may not have an underlying hierarchical "range" and are likely to be made up of non-continuous classes. Classes on such a scale could include, for example, "biodiversity", "water scarcity", "floods", "food production", "energy development" and "hydro-technic infrastructure". These are the kinds of classes in "horizontal" scales or sectors of governance that are often contrasted with the "vertical" ones in multi-level governance systems (Daniell et al., 2011). Each stake or issue can be linked to various "problem-sheds", which can be defined as suitable portions of "space" according to each scale to work out a given issue. For example, on the spatial dimension it may delineate the portion of land that is at stake related to a specific issue. The portions of land associated with each issue (e.g. mining, agriculture, biodiversity protection) may then cross or overlap with each other, creating potential sources of conflict over the resources needed to achieve the objectives of each sector, which most obviously include access to specific quantities and qualities of land and water. Despite often being considered a "horizontal" type of scale, an issue category scale can also take on a more vertical dimension linked to other 
scales that can be related to the granularity of problem identification, such as a problem of regional water scarcity compared to a problem of farm-level irrigation water availability.

In the next section we will discuss the potential mechanisms of interactions between these types of scales and levels, and the other dimensions of grading.

\subsection{Interactions}

There is a range of issues to be considered when interactions occur between processes that take place over a given set of scales and levels with processes taking place in another set. From a governance perspective, it is typically assumed that these interactions are not intended when policies or actions are designed. Yet, in reality, the occurrence of a process at a given set of scales and levels can be found to modify the conditions of occurrence of another process. In other words, externalities are created. These interactions are of different types: multi-level; and multi-scale or cross-scale. We also consider processes of rescaling or scale (re-) construction as a set of important actor interactions, as represented in Figure 2 and discussed below. 


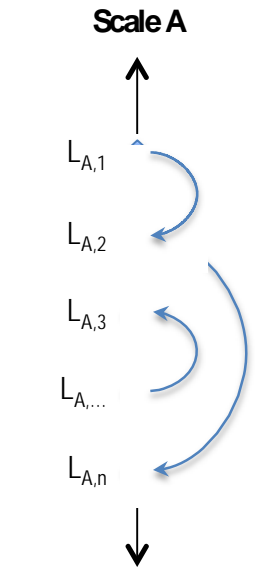

Multi-level interactions

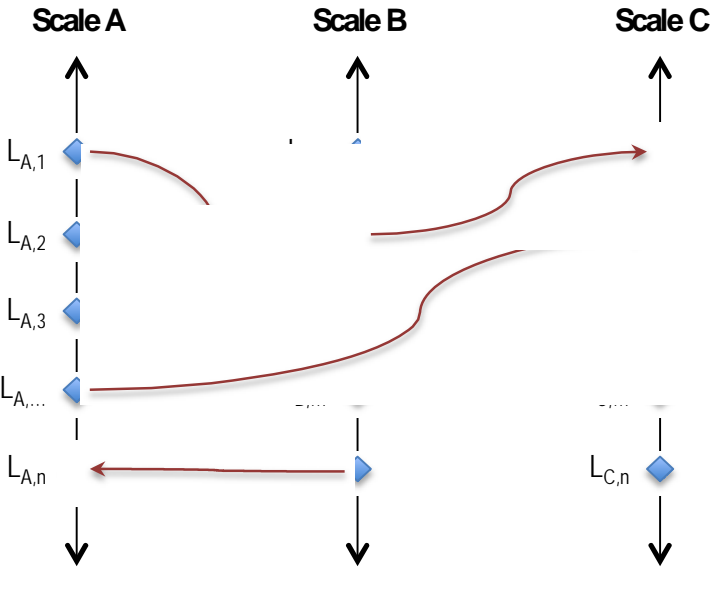

Cross-scale interactions
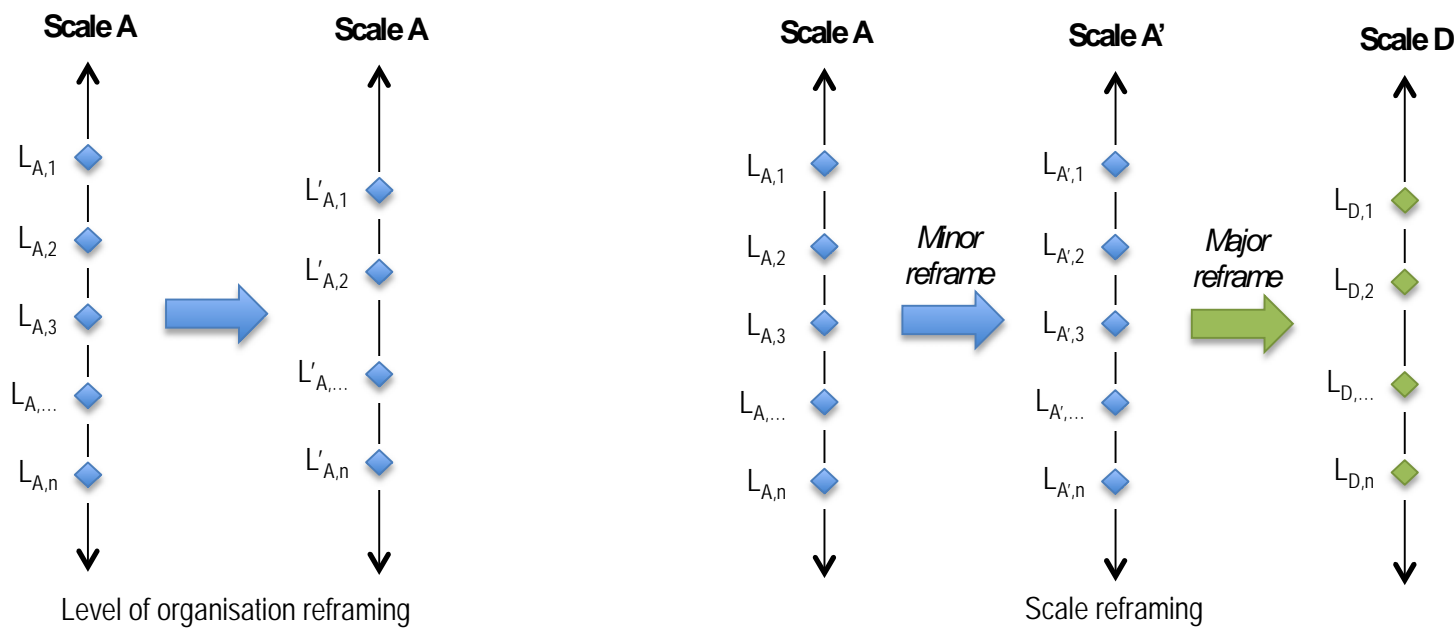

$<$ INSERT FIGURE 2 HERE $>$

\section{Figure 2: Representation of multi-level and cross-scale interactions, and reframing processes}

\subsubsection{Multi-level interactions, considerations and conflicts}

A first type of interaction takes place within a single dimension. Global processes impacting local ones and vice versa are just one such multi-level example based on the spatial and/or administrative scale. These kinds of interactions are commonly acknowledged in the governance literature, including linked to polycentric or adaptive governance (Ostrom, 1999; Marshall, 2008; Pahl-Wostl, 2008) and multi-level governance (Marks and Hooghe, 2004; Bache and Flinders, 2004; Daniell et al., this issue). For example, in multi-level governance, Marks and Hooghe (2004) take the assumption that multiple levels are needed to deal with policy externalities created at other levels. Conflicts across multiple levels of a scale can occur when externalities created by actions or 
decisions at one level create an undesired impact that another level must address. We note here that our "multilevel interactions" would actually be termed "cross-level" by others such as Cash (2006), but for the purposes of discussing water governance in this issue we prefer to stick to the nomenclature that is more typically used in the governance literature.

\subsubsection{Cross-scale interactions, considerations and conflicts}

A second type of interaction takes place from one dimension to another. Processes in a local administration focussed on land management that lead to impacts on processes on national water policy, for example, create cross-scale interactions (as well as multi-level ones), between the administrative, and stakes and issues, scales. Some of the most commonly studied cross-scale interactions are between the spatial and temporal scales (Gunderson and Holling, 2002; Cash, 2006) and increasing numbers of authors are also explicitly looking at crossscale institutional and spatial linkages and potential challenges and conflicts between them (e.g. Wilson et al., 1999; Berkes, 2002; Young, 2002b; Heikkila, 2011; Adger et al., 2005). Again, the multi-level governance literature also speaks about cross-scale interactions between the administrative and stakes scales (e.g. Bache and Flinders, 2004; Daniell et al., 2011) with their various associated "problem-sheds" that cross administrative boundaries.

When considering both multi-level and cross-scale interactions and impacts, it is important to note that scales do not always operate hierarchically, where, for example, the global impacts the local (Sneddon et al., 2002). Many interactions in different directions between levels on one scale, or between scales, can occur, as demonstrated in Figure 2.

\subsubsection{Interactions driving scale construction and rescaling processes}

Actors drive the third kind of interaction. Here "scale" is developed and framed by interactions between actors. From this viewpoint, different scales matter more to particular people and disciplines and can be seen to be more relevant when looking at different phenomena or problems. For this reason, many authors highlight that "scale" - taken broadly under our second definition as "the relative size or extent of something" -is socially constructed (e.g. Smith, 1992; Swyngedouw, 1997; Sneddon, 2002). Here the question of "relative" often relates to what is considered "relevant", and hence, there is a range of politics and interests that can lead to contests 
Author-produced version of the article published in Journal of Hydrology, 2014, N 519 , p. 2367-2380

and processes of constructing scales and "rescaling" (see for example Bourblanc et al., this issue). As

Swyngedouw (1997, p. 140) states: "Scale, both in its metaphorical use and material construction, is highly fluid and dynamic, and both processes and effects can easily move from scale to scale and affect different people in different ways, depending on the scale at which the process operates." Both the reframing of scales as different levels of organisation, and in the adaption of meaning or focus of the whole scale (which could be relatively minor or major), is represented in Figure 2.

As Dovers (2004) notes, once a particular scale is found to be relevant or constructed and a corpus of action developed around it, it is not only important that we reflect on what the particular scale is, but why this scale is important. Most disciplines, interest groups or projects dealing with particular scales are based on an underlying logic on why this scale is relevant. In issues of water governance and resolving conflicts, many different knowledge systems must typically interact, so it is essential to acknowledge not only the scales these actors consider as important, but also why.

We note that considering the social construction and importance of scale does not deny that some external realities exist that are important for hydrological processes and water governance. Yet, there is also an undeniable importance in acknowledging dynamic social relations and shared understandings about scales and the levels considered of importance with them, such as what constitutes a "region", and why this is a relevant concept for establishing water governance measures, conversations and institutions (Sneddon et al., 2002).

\subsection{Theoretical framework for studying scales and interactions}

Our main purpose is to understand the above interactions in order to be better prepared for them in water governance. What are the unintended interactions or impacts of interactions, and what are the arenas where they could be handled?

To investigate this, we require a framework to describe these multidimensional interactions. There a number of frameworks that have been developed for other purposes that could be suitable with adaptions (e.g. Geels and Schot, 2007; Pahl-Wostl et al., 2010; Lubell, 2013; and others described in Binder et al., 2013). However, we have chosen to build on Ostrom's SES framework (Ostrom, 2009) and the IAD framework (Ostrom, 2005) as they are already well known and tailored to describe institutional processes at the interface between nature and society. 
Author-produced version of the article published in Journal of Hydrology, 2014, N 519 , p. 2367-2380

These frameworks have, however, rarely been used for trans-scale processes, being more often presented as ascalar and fitting any scale. Further, these frameworks focus on systems considered as closed in a first approach, or on the conditions to make SES closer to being closed systems, which allows us to specifically study externalities produced by these delimited systems. On the basis of the IAD framework, Ostrom suggests eight principles for good common pool resource management, with the first one being the identification of clear boundaries (Ostrom, 1990; see also Sjah and Baldwin, this issue). Yet, this is rarely possible, at least as far as water is concerned, since social-hydrological systems are at the crossroads of many flows and processes, not just physical water ones. We will thus rather expand on the polycentric governance avenue, which is more suited to the management of multiple complex systems across a variety of scales (Ostrom, 1999): in a complex open system, interactions connect arenas of various types, each of them potentially expanding the network with their own governance systems.

In resilience studies, which often mobilise the SES framework, these issues of changes in scale are also present, for example within the panarchy cycle (Gunderson and Holling, 2002) and through the concept of regime shifts. They focus on the interplay between various sectors of activity, society and the environment (Nelson et al., 2010). Non intended effects are occasionally mentioned as generators of these changes (Walker et al., 2006). Yet, interactions between scales are rarely explicitly described, although a few scholars have started to consider these interactions through such lenses (e.g. Adger et al., 2005; Cumming et al., 2006; Cash, 2006).

In this paper we propose an extension of this body of work focussed on representing these interactions and digging down to their causes through investigation of the diversity of cases provided by the papers in this special issue. The next section reviews these causes while the following one looks at consequences related specifically to governance.

\section{TYPOLOGY OF EXTERNALITIES AND MULTI-LEVEL/CROSS-SCALE}

\section{INTERACTIONS}

We consider that interactions among and across scales (see Figure 2) are due to externalities, or non intended consequences, that emanate from various types of flows. Probably the simplest or most known externality when 
speaking of water is the upstream-downstream issue. Water abstracted in the upstream part of a river basin is no longer available for would-be users in the downstream part. If both parts of the basin are considered separately, the upstream part is said to generate an externality towards the downstream part. The externality is generated in this case by a change in water flow. Pollution transfer is another classical example in water governance. We assume that many externalities can be identified through flows modified by actions on one side of a border, at one level of a given scale. Hence, we try to describe them as such whenever it is possible.

\subsection{Formal externality typology}

We now review the various externalities and flows, material or non material, at the origin of such externalities at the basis of multi-level/cross scale interactions. Water flows and solute flows are obviously among the main ones, but they are far from being the only ones. In total, we consider six types (T1-T6) as follows:

- T1: Physical or material flows (e.g. water, pollution, food, concrete, ecology)

- T2: Information and knowledge (e.g. that could create cognitive changes)

- T3: Political and social control (e.g. that influence who has decision-making power)

- T4: Financial flows (e.g. that can be generated by any entity with access to a bank account or other financial system for exchange)

- T5: Human flows (e.g. people who can travel between spatial or administrative levels)

- T6: Irreversibility effect (e.g. flows, such as that of time passing, which lead to cumulative effects that are difficult or impossible to reverse).

Formally, dynamics at a level on a scale (e.g. $\mathrm{L}_{\mathrm{A}, 1}$ ) can generate an externality (e.g. $\mathrm{T} 1_{\mathrm{a}}$ ) that will then have an impact on dynamics at another level of the same or a different scale (e.g. $\left.L_{H, 2}\right)$. This formal example might represent something such as an increase in water demand from one spatial region which will have an impact on the available resource that a different sector has (e.g. energy production).

For the purposes of the rest of this section we drop the formal language and use specific examples from the papers relevant to water governance to illustrate the worth of this kind of thinking. However, those readers seeking to progress understanding of these kinds of interactions, especially through the use of simulation models, may find the formal definitions particularly useful, especially to explore cascade effects. For example, 
Author-produced version of the article published in Journal of Hydrology, 2014, $\mathrm{N}^{\circ} 519$, p. 2367-2380

The original publication is available at http://www.sciencedirect.com

http://dx.doi.org/10.1016/j.jhydrol.2014.10.055

the Indonesian water sharing case demonstrates how a financial flow generates changes in administrative levels

that, as a consequence, modify physical water flows (Sjah \& Baldwin, this issue)

\subsection{Externality and multi-level/cross-scale interaction examples and descriptions}

In our special issue, there is a range of examples for each type of flow or externality that can be found. Some of these are presented in Table 1, but it is in no way exhaustive of all the possible interaction combinations. Further explanations of each type of flow or externality are then provided.

Table 1: Example externalities and interactions found in the special issue papers

\begin{tabular}{|c|c|c|c|}
\hline $\begin{array}{l}\text { Type of } \\
\text { flow/externality }\end{array}$ & $\begin{array}{l}\text { Process sustaining the flow or } \\
\text { externality }\end{array}$ & $\begin{array}{l}\text { Reference } \\
\text { example(s) }\end{array}$ & Type of scale interaction outlined in reference \\
\hline \multirow{6}{*}{$\begin{array}{l}\text { Water and solute } \\
\text { elements (physical } \\
\text { flows) }\end{array}$} & \multirow[t]{2}{*}{ Upstream-downstream allocation } & Yang et al. & Multi-level spatial \\
\hline & & Gillet et al. & Rescaling of administrative levels \\
\hline & Groundwater availability & Sjah \& Baldwin & Cross scale from administrative levels to issues categories \\
\hline & Increase of demand & $\begin{array}{l}\text { Valdes-Pineda et } \\
\text { al. }\end{array}$ & Cross scale from institutions to sectoral priorities \\
\hline & Inter-basin transfer & $\begin{array}{l}\text { Bourblanc \& } \\
\text { Blanchon }\end{array}$ & $\begin{array}{l}\text { Multi-level spatial and cross scale from spatial to administrative } \\
\text { scale }\end{array}$ \\
\hline & Pollution & Hagemann et al. & Cross scale interactions from administrative to spatial scales \\
\hline \multirow{5}{*}{$\begin{array}{l}\text { Information and } \\
\text { knowledge }\end{array}$} & Heterogeneity of representations & Guerrin et al. & Cross scale from issues categories to institutions \\
\hline & Participatory process & $\begin{array}{l}\text { Mazzega et al.; } \\
\text { Richard-Ferroudji }\end{array}$ & $\begin{array}{l}\text { Cross scale from networks and information to administrative } \\
\text { and management levels }\end{array}$ \\
\hline & Model use & Mazzega et al. & Rescaling on time dimension (horizon of management) \\
\hline & Facilitation activity & Richard-Ferroudji; & $\begin{array}{l}\text { cross-scale (e.g. between knowledge, networks, issues } \\
\text { categories) }\end{array}$ \\
\hline & Statistical analysis & Ward \& Kaczan & Cross scale from information specificity to institutions \\
\hline \multirow[t]{5}{*}{$\begin{array}{l}\text { Political and social } \\
\text { control }\end{array}$} & $\begin{array}{l}\text { Legitimacy on groundwater } \\
\text { regulation }\end{array}$ & Ross & Mismatch between institutions and spatial scales \\
\hline & $\begin{array}{l}\text { Legitimacy on catchment } \\
\text { management }\end{array}$ & $\begin{array}{l}\text { Bourblanc \& } \\
\text { Blanchon; } \\
\text { Houdret et al. }\end{array}$ & $\begin{array}{l}\text { Cross scale and rescaling from spatial to administrative and } \\
\text { institutional scales }\end{array}$ \\
\hline & $\begin{array}{l}\text { Political reform in transition state } \\
\text { (towards more legitimacy) }\end{array}$ & Hagemann et al. & $\begin{array}{l}\text { Cross scale interactions from administrative scale to spatial } \\
\text { scale }\end{array}$ \\
\hline & Coalitions on innovation uptake & Daniell et al. & $\begin{array}{l}\text { Cross scale and rescaling from administrative scale levels and } \\
\text { issues categories to institutional scale levels }\end{array}$ \\
\hline & Governance structures on justice & Patrick et al. & $\begin{array}{l}\text { Cross scale and rescaling on spatial, administrative and } \\
\text { institutional scales to issues categories and perceptions } \\
\text { (knowledge scale) }\end{array}$ \\
\hline \multirow[t]{2}{*}{ Financial flows } & Economic aggregation & Yang et al. & Multi-level institutional interaction and rescaling \\
\hline & Fee payments/budget transfers & $\begin{array}{l}\text { Sjah \& Baldwin; } \\
\text { Daniell et al. }\end{array}$ & $\begin{array}{l}\text { Cross scale from issues/network categories to administrative } \\
\text { levels, or multi-level between administrative levels }\end{array}$ \\
\hline \multirow[t]{2}{*}{ Human flows } & Data availability & Hagemann et al. & Multi-level on information specificity \\
\hline & Brokering work & Daniell et al. & $\begin{array}{l}\text { Multi-level administrative and cross-scale (e.g. between } \\
\text { knowledge, networks, issues categories) }\end{array}$ \\
\hline Irreversibility effect & Historical framing & Guerrin et al. & Multi-level temporal \\
\hline
\end{tabular}




\begin{tabular}{|l|l|l|l|}
\hline & Worldviews, norms of justice & $\begin{array}{l}\text { Gross \& } \\
\text { Dumaresq }\end{array}$ & Multi-level temporal \\
\hline
\end{tabular}

The first category, physical flows, for which we have examples based on water and solute elements, are unsurprisingly the most obvious type of flows of interest to water governance and are frequent sources of interactions among scales. They connect spatial levels, even beyond catchment and basin boundaries as far as interbasin transfers are concerned. They are also directly impacted by any change in the conditions of resource renewal and use. For example, in Chile historical tacit agreements on resource sharing are hampered by fast increases in demand for irrigation in concentrated areas, which, in a context of climate change, lead to the need to envisage alternative management actions at a higher administrative and spatial level (Valdes-Pineta et al., this issue).

Then come two types of non material flows: firstly, information and knowledge; and secondly, power and control through political and social means.

In information and knowledge externalities, we include all the transfers of representations, beliefs and data about the social-hydrological system. These flows stem from the diversity of viewpoints on relations to water in any kind of arena that aims at producing a type of integration or aggregation (for example, a water planning process). This includes some kinds of multi-scale interaction or "upscaling" where the outcome of the aggregation process can be located in another dimension, hence inducing cross-scale interactions. The origin of such a flow is typically in a lower level of a scale (including networks, issue categories or information specificities) and modifies the state of higher levels, such as those on the management and institutional scales. Gathering a diversity of information appears not to be sufficient to reach success in the aggregation process, as there is also a need to have compatibility in frames inherent in each information source. One example is also present on the temporal scale, thanks to the opportunity given by association of diverse sources of information in simulation devices to grasp longer time spans at a glance in a decision-making process (Mazzega et al, this issue).

Through political and social control, named "hydrosocial flows" (see Bourblanc and Blanchon, this issue), we include primarily the issue of legitimacy of actors that are supposed to control the use and movement of water, and how governance structures and actor coalitions shape water management decisions and outcomes. 
Author-produced version of the article published in Journal of Hydrology, 2014, N519, p. 2367-2380

The original publication is available at http://www.sciencedirect.com

http://dx.doi.org/10.1016/j.jhydrol.2014.10.055

Perceived scale mismatches, for example between spatial and administrative levels, commonly generate (or at least call for) the need to reform scales of water governance, often leading to the development of new administrative levels such as river basin management authorities. The cases presented in this special issue provide various ways to generate these changes in control according to the spatial entity of reference (groundwater, river basin) and current stabilization of the administrative scale structure in countries like the Ukraine (Hagemann et al., this issue). The cases also present innovative approaches based on how power flows and human action can attempt to make specific water related innovations meaningful beyond their own "problem-sheds", potentially generating rescaling processes across a number of dimensions (Daniell et al., this issue).

The next category of flow deals with finance and economics, within which two distinct processes emerge. Onefee payments or budget transfers-is often cross-scale in the case of fee payments (e.g. from water users to governments) or multi-level on the administrative scale in the case of budget transfers (e.g. from a national government to a basin authority or local government), while the second one-economic aggregation-leads to multi-level interactions and possibilities of upscaling. Changes in conditions to access resources can be obtained through buying rights. Conditions for this are not the same among issue categories; the causes for this include the difference in economic margins generated by water use according to industry. For example, they are much higher in the tourism industry than in livelihood farming, for example in Sjah and Baldwin's Indonesian case (this issue). This makes an interaction between the administrative scale, under which the fee system is set up, and the issue category scale. The second process is a way to deal with spatial scale concerns and the water flows mentioned earlier through upscaling policy assessment systems. Economic aggregation at an upper spatial level of losses and benefits of water sharing reform at small spatial levels could provide a way forward for more efficient water allocation. However, this also requires cross scale interactions with the institutional scale so that a fair and trusted transfer of benefits is granted (Yang et al., this issue).

The following category of possible human flows is not as strongly represented in the cases in this special issue. People through their distribution across land, their mobility and their participation in a diversity of management and administrative arenas can be the sources of multi-scale, cross-scale or rescaling interactions. Typically, representatives of a community acting in a project could transmit their community members' representations to 
another scale level. People are also the bearers of data, knowledge or producers of actions that remain unharmonised when they are scattered across different institutional levels, which make them unusable at the basin spatial and administrative scale (Hagemann et al., this issue). For example, they can also physically work at, or across, multiple levels and scales, brokering information and knowledge, or facilitating its transfer, on different issues categories between people or different administrative levels (Richard-Ferroudji, this issue; Daniell et al., this issue).

Finally, a last category of externality is not mediated by any flow but categorized by what we term as an irreversibility effect. This category of externality generates multi-level interactions in the time scale. Classical examples are due to decisions under uncertainty that drive further choices (Henry, 1974). These happen, for example, with decisions related to the financing of infrastructure to cope with water, distribution, scarcity or flood risks and can lead to lock-in of water systems and associated governance systems that are difficult to change (Daniell et al., this issue). For example, when a decision is made to finance a dam being built, it calls for new investments justified by the dam's existence. In this special issue, there are other more original examples of the irreversibility effect. Both are based on the framing of actions due to slow changes in frame representations of stakeholders, such as worldviews and norms of justice (Gross and Dumaresq, this issue) or rationalization of a decision at a moment that structures further decisions accordingly (Guerrin et al., this issue). In other words, people's representations that may have otherwise evolved at a faster pace become stuck and difficult to change.

\section{DISCUSSION: WATER GOVERNANCE ACROSS COMPETING SCALES}

Considering the definitions, examples and typology previously described, we now turn to the investigation of our initial questions presented in the introduction and how the contributions to this special issue help us to respond to them. To preface our extended discussion, we first provide a full summary of the Special Issue contributions and scale-related foci of each article in Table 2, as only a few aspects of them have so far been highlighted in Section 3. We then move on to responding to our initial questions in turn:

- How are conflicts across competing scales managed?

- What mechanisms are involved in bridging scales? 
Author-produced version of the article published in Journal of Hydrology, 2014, N ${ }^{\circ} 519$, p. 2367-2380

The original publication is available at http://www.sciencedirect.com

http://dx.doi.org/10.1016/j.jhydrol.2014.10.055

- To what extent are currently privileged scales and/or governance structures appropriate for effectively managing water? And what might be more appropriate, for example to cope with changing regional climate and demand patterns?

Table 2: Special issue article foci on scales, interaction types and externalities or flows considered. The key of the foci is as follows: $\mid$ - primary focus; $\odot$ - secondary focus; $\bullet-$ implicitly present behind article arguments and/or case(s) studied

\begin{tabular}{|c|c|c|c|c|c|c|c|c|c|c|c|c|c|c|c|c|c|c|}
\hline \multirow[t]{2}{*}{ Author } & \multirow[t]{2}{*}{ Title } & \multicolumn{8}{|c|}{ Scales considered } & \multicolumn{3}{|c|}{$\begin{array}{l}\text { Interactions } \\
\text { considered }\end{array}$} & \multicolumn{6}{|c|}{$\begin{array}{l}\text { Externality/flow } \\
\text { considered }\end{array}$} \\
\hline & & 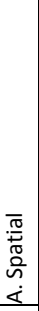 & 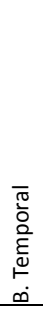 & 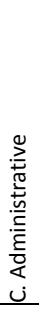 & 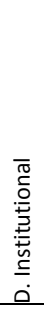 & 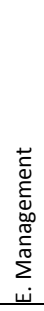 & 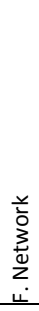 & 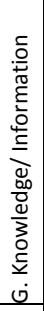 & 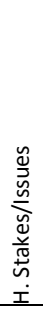 & 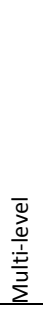 & 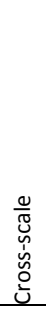 & 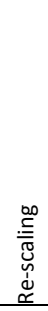 & 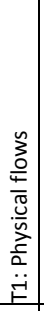 & 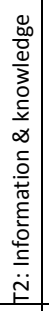 & 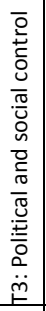 & 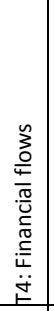 & 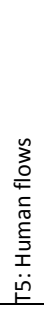 & 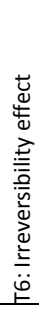 \\
\hline $\begin{array}{l}\text { Bourblanc \& } \\
\text { Blanchon }\end{array}$ & $\begin{array}{l}\text { The challenges of rescaling South African water resources } \\
\text { management: Catchment Management Agencies and inter-basin } \\
\text { transfers }\end{array}$ & | & $\odot$ & $\mid$ & $\mid$ & $\cdot$ & $\odot$ & $\bullet$ & | & $\odot$ & $\cdot$ & | & $\mid$ & $\odot$ & | & $\mid$ & $\odot$ & $\odot$ \\
\hline Daniell et al. & Politics of Innovation in Multi-Level Water Governance Systems & $\odot$ & $\odot$ & & & $\odot$ & & & t & $T$ & 7 & $\cdot$ & $\odot$ & & & & & \\
\hline Gillet et al. & $\begin{array}{l}\text { Moving from local to State water governance to resolve a local } \\
\text { conflict between irrigated agriculture and commercial forestry in } \\
\text { South Australia }\end{array}$ & $\odot$ & $\odot$ & $\mid$ & 1 & $\odot$ & • & $\bullet$ & $\mid$ & | & | & | & $\odot$ & $\mid$ & | & $\bullet$ & $\odot$ & • \\
\hline $\begin{array}{l}\text { Gross \& } \\
\text { Dumaresq }\end{array}$ & $\begin{array}{l}\text { Taking the longer view: timescales, fairness and a forgotton story of } \\
\text { irrigation in Australia }\end{array}$ & $\odot$ & | & $\odot$ & $\odot$ & $\bullet$ & $\bullet$ & $\mid$ & $\mid$ & 1 & | & - & $\odot$ & 1 & $\odot$ & $\odot$ & $\odot$ & $\mid$ \\
\hline $\begin{array}{l}\text { Guerrin et } \\
\text { al. }\end{array}$ & $\begin{array}{l}\text { "Functional fit" versus "politics of scale" in the governance of } \\
\text { floodplain retention capacity }\end{array}$ & 1 & $\odot$ & $\mid$ & | & | & • & $\odot$ & $\mid$ & | & 1 & | & | & $\odot$ & | & $\odot$ & $\odot$ & $\mid$ \\
\hline $\begin{array}{l}\text { Hagemann } \\
\text { et al. }\end{array}$ & $\begin{array}{l}\text { The long road to improving the water quality of the Western Bug } \\
\text { River (Ukraine) - A multi-scale analysis }\end{array}$ & । & 1 & 1 & 1 & 1 & $\bullet$ & • & 1 & 1 & 1 & $\bullet$ & 1 & $\odot$ & 1 & | & • & $\odot$ \\
\hline $\begin{array}{l}\text { Houdret et } \\
\text { al. }\end{array}$ & $\begin{array}{l}\text { The institutionalisation of River Basin Management as politics of } \\
\text { scale - Insights from Mongolia }\end{array}$ & 1 & $\odot$ & $\mid$ & 1 & $\mid$ & $\bullet$ & • & $\mid$ & $\odot$ & $\bullet$ & | & $\bullet$ & • & | & | & $\bullet$ & • \\
\hline $\begin{array}{l}\text { Mazzega et } \\
\text { al. }\end{array}$ & $\begin{array}{l}\text { Critical multi-level governance issues of integrated modelling: an } \\
\text { example of low-water management in the Adour-Garonne Basin } \\
\text { (France) }\end{array}$ & | & | & $\mid$ & $\mid$ & $\odot$ & $\odot$ & $\odot$ & $\mid$ & $\mid$ & | & $\bullet$ & $\mid$ & $\odot$ & $\odot$ & $\mid$ & $\bullet$ & | \\
\hline Patrick et al. & $\begin{array}{l}\text { How reframing a water management issue across scales and levels } \\
\text { impacts on perceptions of justice and fairness }\end{array}$ & 1 & $\odot$ & $\mid$ & 1 & $\bullet$ & $\odot$ & 1 & 1 & 1 & 1 & | & 1 & 1 & 1 & $\bullet$ & $\cdot$ & $\odot$ \\
\hline $\begin{array}{l}\text { Richard- } \\
\text { Ferroudji } \\
\end{array}$ & $\begin{array}{l}\text { Rare birds for fuzzy jobs: a new type of water professional at the } \\
\text { watershed scale in France }\end{array}$ & 1 & $\odot$ & $\odot$ & $\odot$ & $\odot$ & $\mid$ & $\mid$ & $\mid$ & $\odot$ & | & | & $\bullet$ & 1 & | & $\bullet$ & | & • \\
\hline Ross & $\begin{array}{l}\text { Banking for the future: prospects for integrated cyclical water } \\
\text { management }\end{array}$ & 1 & $\mid$ & $\odot$ & | & | & $\odot$ & $\bullet$ & $\mid$ & 1 & 1 & • & $\mid$ & $\bullet$ & | & | & $\bullet$ & • \\
\hline $\begin{array}{l}\text { Sjah and } \\
\text { Baldwin }\end{array}$ & $\begin{array}{l}\text { Options for future effective water management in Lombok: a multi- } \\
\text { level nested framework }\end{array}$ & 1 & $\odot$ & $\mid$ & 1 & $\odot$ & $\mid$ & $\mid$ & $\mid$ & 1 & $\mid$ & • & 1 & $\odot$ & $\mid$ & | & $\odot$ & • \\
\hline $\begin{array}{l}\text { Valdes- } \\
\text { Pineda }\end{array}$ & $\begin{array}{l}\text { Water governance in Chile: availability, management and climate } \\
\text { change }\end{array}$ & 1 & 1 & $\mid$ & | & $\odot$ & • & $\odot$ & $\mid$ & | & 1 & $\bullet$ & 1 & 1 & 1 & $\bullet$ & $\bullet$ & $\odot$ \\
\hline $\begin{array}{l}\text { Ward and } \\
\text { Kaczan }\end{array}$ & $\begin{array}{l}\text { Changing Hydrological Panaceas: water poverty governance } \\
\text { accounting for spatial scale in the Niger Basin }\end{array}$ & | & • & $\mid$ & $\mid$ & $\bullet$ & • & | & $\mid$ & 1 & 1 & • & $\mid$ & 1 & 1 & | & $\odot$ & • \\
\hline Yang et al. & $\begin{array}{l}\text { Water governance and adaptation to climate change in the Indus } \\
\text { River Basin }\end{array}$ & 1 & 1 & 1 & 1 & $\odot$ & $\bullet$ & $\odot$ & $\mid$ & $\mid$ & | & - & | & $\odot$ & | & 1 & • & | \\
\hline
\end{tabular}

\subsection{Managing conflicts across competing scales}

Through the theoretical aspects of this paper and the examples presented in the articles of this special issue, we can observe that there is a range of conflicts that occur across scales and levels within them. One of the most common is "mismatch" when there is a perceived poor fit between two scales, for example, defined 
Author-produced version of the article published in Journal of Hydrology, 2014, N519, p. 2367-2380

The original publication is available at http://www.sciencedirect.com

http://dx.doi.org/10.1016/j.jhydrol.2014.10.055

administrative structures and spatial territories or between an actor network and the water management stakes/issues requiring management (e.g. Folke et al., 1998; 2007; Moss and Newig, 2010; Syme et al., 2012;

Patrick et al., this issue). This kind of conflict is typically managed by either trying to rescale systems to achieve a "better fit" or by the most powerful players developing coalitions that manage the conflicts indefinitely with the resultant outcomes furthering their own interests - an approach that we could suggest is "pure politics". In our issue, there are a number of articles that treat mismatch issues. For example, Daniell et al. (this issue) investigates the effects and resulting politics of the mismatch between the promoting actor network sizes and implementation territories of more "sustainable" or "participatory" water innovations, compared to those of the current (entrenched) water governance systems that typically have broader legal, administrative and spatial remits. Ross (this issue) looks at a mismatch on the stakes/issues levels of ground-water and surface water with the corresponding institutional, temporal and spatial scale levels, showing how systems in the Colorado (US) and Namoi (Australia) are not set up to facilitate effective integrated cyclical water management. Similar issues and mismatches between water resources across the Chilean territories and needs of sectors and populations (stakes/issues levels) are also described in Valdes-Pineda et al. (this issue).

The question of what can be done to manage such mismatch conflicts, either between levels or scales, is complex and depends greatly on who seeks to actually resolve or manage the conflict and why. Powerful actors may seek to resolve (or maintain) the conflict in its current state for their own comparative gain, or there may be actors who are seeking conflict resolution for a range of other objectives, including promoting more equitable and just access to land and water, improving system environmental quality or promoting democratic decisionmaking on water governance. The mechanisms that these different actors may be able to use for conflict management (or to work against each other) vary greatly, as detailed both here and in the next Section 4.2.

Firstly, to prevent management of a conflict by the more powerful (e.g. National level water departments, as described in Bourblanc and Blanchon, this issue) when it is not necessarily seen as legitimate, the analysis developed so far in this paper suggests some entry points. Identification of externalities or flows, including irreversibility effects, can be one such useful entry point, and requires reference levels on both sides of interactions to be made explicit. Such an identification process does not aim at merging all reference levels into an illusory common suitable level across scales, but provides a basis for actors involved in the conflict to 
understand the logic and constraint of other actors and to uncover to what extent there is potential for complementarity of actions resulting in mutual (or greater overall) benefits. This raises the need to facilitate exchanges among these actors on their social-hydrological systems, and to identify suitable mechanisms and tools that can be used for this purpose.

While water-related conflicts often materialize around issues of access to, and use of, land or resources (including water) located in these pieces of land, a key principle in moving conflict resolution forward is to shift the focus from entrenched understandings of the conflict to an alternative understanding (i.e. problem reframing), so that more positive discussions can emerge. For example, in a conflict related to land control and water use in Massachusetts, developing interactions around a "Politics of place" approach allowed the community to reframe the conflict and shift to valuing the place at the intersection of the various key actors' points of view (Steinberg and Clark, 1999). Patrimonial approaches also aim to shift discussions on conflicts along the time scale-with a strong focus on the future-so that world views and expectations come first to help establish a positive context, before operational issues of the present are considered (Babin et al., 1999). Yet, even within such approaches, major differences in worldviews may mean that certain coalitions of actors (which may stem from different scale levels) could use or avoid participating in such fora to maintain existing governance regimes in place (Daniell et al., this issue; Gillet et al., this issue).

The next section provides further propositions to facilitate more effective bridging or constructive dialogue across scales and levels.

\subsection{Mechanisms for bridging scales and levels}

The general mechanisms commonly evoked in the literature for bridging scales and levels (e.g. Cash et al., 2006) in any social-ecological system setting include:

- institutional interplay: development of interaction between administrations and management organisations, and harmonisation or complementarities between different rules (e.g. laws, operating rules);

- co-management: power and responsibility sharing between governments/managing authorities and communities; and 
Author-produced version of the article published in Journal of Hydrology, 2014, N519, p. 2367-2380

The original publication is available at http://www.sciencedirect.com

http://dx.doi.org/10.1016/j.jhydrol.2014.10.055

- boundary or bridging organisations: groups that facilitate knowledge and information exchange between actors associated with different scale levels.

All of these mechanisms can be seen to be functioning in the governance of the social-hydrological systems cases in this special issue.

For example, examples of institutional interplay and how it can be enhanced are provided, including through the development of: water planning mechanisms and creation of new institutional structures such as interdepartmental committees (Gillet et al., this issue); mechanisms for information sharing and division of labour (Hagemann et al., this issue); legal and territorial reforms (Hagemann et al., this issue) or institutional (re-)design (Ross, this issue).

The articles then present a range of integration and collaboration approaches, including collective decisionmaking approaches or "co-management", for example at the basin scale, which allow interests, knowledge and resources to be brought together in an attempt to reduce transaction costs across jurisdictional boundaries (Memon and Weber, 2008; Hagemann, this issue). Similarly, but based more on conflict resolution, through negotiation of tension, conflicts and contradictions, agreements on new governance scales can be made that will influence future practice (Swygendouw, 2010; Houdret et al., this issue). The musyawarah consensus-based approach to decision-making in Lombok (Indonesia), discussed by Sjah and Baldwin (this issue), is just one such example. Model development (Yang et al., this issue), including through participatory processes and scenario development (Mazzega et al., this issue), or water use organisations (Valdez-Pineda et al., this issue) are also provided as tools or mechanisms for bridging levels and scales that can support co-management practice.

Closely linked to how such co-management systems can be set up and maintained is the third category of boundary organisations, "spanners" or different types of intermediaries (Moss et al., 2009). The importance of having people and organisations playing the role of bridging levels and scales and ensuring the transfer of knowledge and information between them has been a point well articulated in a number of articles that explore 
the roles of bridging organisations (Sjah and Baldwin, this issue), brokers (Daniell et al., this issue) or facilitators, policy entrepreneurs or stewards (Richard-Ferroudji, this issue).

However, beyond these collaborative mechanisms and the people and objects that can be used to support them, some case studies presented in this special issue report a couple of other mechanisms based on more confronting relations. For example, to ensure maintenance or social or political positions, powerful stakeholders can also work across levels or scales, reframing problems (and the extent of relevant "problem-sheds") and seeking to rescale (often upscale) water governance processes. In particular, a number of authors point to the possibility of moving up a level or across scales to garner support for their processes and objectives physically situated at lower administrative or spatial levels, which in some cases could lead to higher levels of governance imposing or coordinating water governance activity at lower levels (Daniell et al., this issue; Gillet et al, this issue; Hagemann et al., this issue). A different strategy that less powerful actors could use against a stronger or entrenched water governance regime that is identified is to work to increase the level of "contextualisation" (David, 1999) of a water related innovation in the existing system (Daniell et al., this issue), which can be seen as synonymous to finding an appropriate niche or "fit" where it can flourish. Another strategy identified is to change the scale of evaluation or the contour of the issue so that benefits are computed in a "suitable" way. This requires a certain power to be able to force or enact such change, but when enacted may allow the reframers to maintain this power. A key in this strategy is to determine the appropriate scale required to generate statistical results that satisfy the actors involved. The associated challenges in doing this are reflected in the water poverty analyses in the Niger Basin where different levels of spatial analysis produce different statistical results (Ward and Kaczen, this issue). Two other articles in this special issue showcase the potential of upscaling with economic and resource assessment in Pakistan (Yang et al., this issue) and justice assessments of small dams and associated water allocation opportunities in Australia (Patrick et al., this issue). As in changes in electoral boundaries for political voting, altering boundaries or scales can be seen as a classic means of altering probabilities of outcomes.

\subsection{Privileged scales, water governance structures and alternatives}


Author-produced version of the article published in Journal of Hydrology, 2014, N 519 , p. 2367-2380

The original publication is available at http://www.sciencedirect.com

http://dx.doi.org/10.1016/j.jhydrol.2014.10.055

The last questions to be treated here are to what extent are currently privileged scales and/or governance structures appropriate for effectively managing water? And what might be more appropriate, for example to cope with changing regional climate and demand patterns?

Looking first at currently privileged scales, from Table 2 and our review of the water governance literature it appears that the most commonly evoked scales are spatial and administrative scales with their corresponding institutional scales (e.g. laws or water management rules applicable at an administrative level that has a corresponding territorial remit). The stakes/issue scales, although much less explicitly discussed, are almost always present in discussion of water governance specifics, such as over water use sectors (e.g. human use, environment, agriculture) and land-use patterns. Likewise, the temporal scale is often implicitly present but often not discussed as such, unless the water governance work has a strong hydrological process, simulation modelling or historical narrative focus (e.g. Gross and Dumaresq, this issue; Mazzega et al., this issue; ValdezPineda et al., this issue). The exception occurs when talking about timeframe misfits between political processes and others, such as ecological processes (e.g. Hagemann et al., this issue). The network scale is evoked by authors studying fine-grained actor systems or water distribution systems (e.g. Bourblanc and Blanchon, this issue; Daniell et al., this issue), but otherwise remains implicit or hidden in this collection of papers. There are similar stories for the management scale and knowledge/information scales, with only a few authors paying them a significant amount of attention (See Table 2).

If we dig down into this general overview, we observe that some of the most commonly privileged spatial scales and associated governance structures promoted for water management are the river basin, catchment and associated administrative structures based on these spatial levels, such as Water Basin Authorities or Catchment Management Agencies. The uptake of integrated water resources management (IWRM) (GWP, 2000; Snellon and Schrivel, 2004; Conca, 2006; Jeffrey and Gearey, 2006) or River Basin Management more generally (e.g. Downs et al., 1991; Squires et al., 2014) has been promoted internationally for many years now and has thus led to many attempts to implement the principles of "basin-based" water governance or just more "integrated" management across scales and levels. The movement from traditional administrative and institutional scales based on political representation across defined spatial territories to "hydrologically" defined basins with new 
Author-produced version of the article published in Journal of Hydrology, 2014, N 519 , p. 2367-2380

The original publication is available at http://www.sciencedirect.com

http://dx.doi.org/10.1016/j.jhydrol.2014.10.055

administrative structures and institutional mechanisms to fit them has, however, not escaped criticism and heated debate in some quarters (including Bourblanc and Blanchon, this issue; Houdret et al., this issue). A couple of the main arguments about the appropriateness or inappropriateness of such coupled scales which appear in the articles of this special issue and the greater literature are that:

1) Basins or catchments used for water governance with matching administrative structures and institutional mechanisms are commonly not just based on a physical hydrological/topographical definition; they are, in fact, social constructions based on a range of economic, political and sociocultural factors as well (e.g. Harris and Alatout, 2008; Warner et al., 2008; Bourblanc and Blanchon, this issue). This does not mean that those that are chosen are inappropriate, but this political definition can support and/or hinder the efficacy of governance processes carried out at this level, as discussed by Bourblanc and Blanchon (this issue) and Houdret et al., (this issue).

2) Basins or catchments may be irrelevant constructions in many areas where there are inter-basin transfers, heavily modified or engineered water systems that cross basin boundaries, important surface water-groundwater connections (where ground-water systems do not "fit" surface water topological boundaries), or where the issues, people or governance regimes impacting that territorial area are not only from inside the boundary. In such situations, which could apply to the majority of water governance problems, there are a number of authors who advocate taking a "problemshed" approach, instead of a "watershed" one, where "issues-networks" around water governance are the main way of making boundary judgements about appropriate scale/level choices (e.g. Allan, 1998; Loucks, 1998; Mollinga et al., 2007; Bourblanc and Blanchon, this issue). We note, however, that defining problemsheds in practice for the purpose of creating formal institutions may prove even more challenging than defining basins for this purpose at higher spatial levels (inter-state or inter-region). From the observations in our contributions and other literature, problemsheds may be a more effective construction for highly engineered systems (such as in urban areas) or shorter-term or informal governance processes at regional levels or lower with clear decision-making objectives. This might include those defined for specific "decision-aiding processes" or those trying to incite innovation uptake at the regional level (e.g. Tsoukias, 2007; Daniell, 2012; Daniell et al., this issue), or for decision-support 
Author-produced version of the article published in Journal of Hydrology, 2014, N 519 , p. 2367-2380

The original publication is available at http://www.sciencedirect.com

http://dx.doi.org/10.1016/j.jhydrol.2014.10.055

systems and modelling with locally important management structures and institutions (Ostrom, 1990;

Mazzega, this issue; Yang et al., this issue).

In any case, the basin or catchment cannot be the only reference scale. Governance taking into account the interaction between scales needs to be open towards the multiplicity of references that are borne by the various actors involved in particular problemsheds. The french concept of "territoire" (territory) as the portion of land physically and cognitively appropriated by a group of people (Buleon and Di Meo, 2005), close to the concept of a social-ecological system, is a good candidate to serve as the basis for a useful water governance problemshed, thanks to its blurred boundaries which depend on people's representations. It matches the polycentric governance trend (Ostrom, 1999; Marshall, 2008) since it is defined according to a group of people, whose members may feel part of several "territoires" (territories).

These arguments are closely linked to the type of arguments common in the "politics of scale" (and place) and political ecology literature on water governance (see Norman et al., 2010, for an overview), including those on the "hydrosocial cycle" (Budds, 2009; Linton and Budds, 2014; Bourblanc and Blanchon, this issue; Guerrin et al, this issue) or to the ecological and associated institutional economics literature on "functional fit" (see Guerrin et al., this issue) where it is suggested that water managers and academics need to move away from considering water as a physically constrained resource, to considering it as a social-ecological process, hence explicitly recognising the interconnected nature of human institutions and practices on water and its linked systems, and vice-versa. This will allow political and other drivers of water governance and its entrenchment and/or change to be understood and possibly better managed in future reform periods; including what administrative structures and institutional mechanisms, or other water-related innovations or practices, are likely to be successfully taken up in specific environments (Daniell et al., this issue). Looking at multi-level and cross-scale interactions linked to justice, Patrick et al. (this issue) also point out the importance of the related social constructionist concept of framing, or "re-framing", that occurs when people frame issues from the perspective of one level on a scale or another; for example, something considered just at the local level may appear unjust at the regional level. Likewise, when considering integrated cyclical water management, institutions need to be redesigned for the 
extent and type of not only contributing surface water systems, but also their connecting (through natural or engineered means) groundwater systems (Ross, this issue).

\section{CONCLUSIONS AND PERSPECTIVES}

From our theoretical framework and analyses supported by the papers in this special issue, we can point to four specific arrangements in water governance across competing scales that appear particularly important in order to control the different flow types between levels and scales and to manage their consequences.

First, the emerging set of basin-based water institutions and administrations cannot be the sole answer to developing "good" water governance. These organisations are useful in dealing with water and solute flows (except in inter-connected trans-basin settings) but not necessarily the other flow types. They are also good candidates to serve as arenas to organise collective action, even in clearly open social-hydrological systems. However, flows of knowledge and irreversibility effects limit their effectiveness in the operationalization of agreements (Guerrin et al., this issue). There is thus a need to integrate the "wider socio-economic catchment context" (Syme et al., 2012) and hence investigate the viability of developing problemshed governance arrangements. Polycentric governance (Ostrom, 1999) or multi-level governance (Bache and Flinders, 2004) paves the way for adjustment and coordination between various arenas, including at least one in charge of water and solute flows.

Second, governance needs to include affected parties in the scales impacted in the interactions. This is a way to internalize externalities, as recommended by Syme et al. (2012), based on an insight that stems from their research in India. It is also a way to ensure that multi-level interactions are profitable to all, as could be the case in the Indus valley investigation of Yang et al. (this issue), provided that sufficient trust can be built around water reallocation. Such inclusion of externalities requires constant adaptation to cope with the chain of arenas connected by the various flows. Operational protocols have to be designed to make clear boundary judgements on these systems and clear analyses of people impacted each time policies or rules are adjusted. In this way there is a greater possibility for effectively incorporating these actors into the official governance processes of 
Author-produced version of the article published in Journal of Hydrology, 2014, N 519 , p. 2367-2380

The original publication is available at http://www.sciencedirect.com

http://dx.doi.org/10.1016/j.jhydrol.2014.10.055

the social-hydrological system and for detecting further adjustments that need to be made to the governance regime.

Third, there is a need for greater coupling of, and coordination between, people and institutions. Several flows and externalities are rooted in administrative and/or institutional scales on the one hand, and on issue categories on the other hand. These scale interactions lead to the necessity of incorporating a variety of actors' stakes into institutions. However, such work is complicated and examples provided in this issue show that it is not always possible, or successful, in reaching governance objectives such as the development of collective agreements. Dedicated individuals or organisations such as "facilitators" (Richard-Ferroudji, this issue), "brokers" (Daniell et al., this issue) or "boundary workers" (Hoppe, 2010) are required to help at this level and the importance of their role and the skills required to carry it out effectively should not be underestimated.

Fourth, these multiple flows and externalities generate unstable states in social-hydrological systems. This effectively means that adaptive governance is required, which entails the continual development and use of innovative approaches that adapt to new needs and situations. Recent progress in participatory research is now helping to work out some apparent oxymorons such as "adaptive planning" by developing processes which allow multi-level and cross-scale involvement of stakeholders and continuous social learning to drive ongoing, but planned, adaptation (Ferrand et al., 2013). This is work in progress in various cases across the world. It builds on a tradition of using a diversity of simulation and experimental artefacts with stakeholders in order to undertake effective boundary work and to generate safer spaces for reflection on water governance (Le Page et al., 2011; Barreteau et al., 2012; Daniell, 2012).

All of these arrangements entail extending hydrological analyses, which explore water and solute flows, to investigating the consequences of different decision-making actions on social-hydrological systems in their multiple dimensions. Similar patterns of work exist using concepts of virtual water or water footprint for policy exploration (Allan, 1998; Aldaya et al., 2010; Barreteau et al., 2010; Ridoutt and Pfister, 2010), but at a less aggregated and more mechanistic level. We propose that such analyses could be extended to all categories of 
flows or externalities to understand potential impacts of policies related to water and water-use regulation within social-hydrological systems across the globe.

The development of our typology, only so far used to investigate the cases found in 15 papers from different areas of the world, could be further tested and expanded to help with this challenge. This would require not only additional theoretical work, but also a plethora of researchers and practitioners willing to engage across competing levels and scales of water governance to drive more effective water and land management, and exchange knowledge on the results of their work and how it might be further improved.

\section{ACKNOWLEDGEMENTS}

The idea for this Special Issue originated from the first forum of the French-Australian Initiative on Water and Land Management, held in Montpellier, France, in June 2011. We would like to thank all of the participants of this forum for their involvement in discussions on this topic and subsequent authors and reviewers who have contributed to this collection and improved its quality. We are also very grateful to Prof. Geoff Syme for his ongoing support of this Special Issue throughout its development and realisation, as well as the production team at Elsevier.

\section{REFERENCES}

Ackmouch, A. 2011. Good Governance: Synthesis Report, Sessions Proposal and Next Steps for the Condition for Success 1 , Report to the $6^{\text {th }}$ World Water Forum, OECD, Paris.

Adger, W.N., Brown, K. and Tompkins, E.L. 2005. The political economy of cross-scale networks in resource comanagement. Ecology and Society 10(2): 9. [online] URL: http://www.ecologyandsociety.org/vol10/iss2/art9/

Aldaya, M.M., Martínez-Santos, P., Llamas, M.R. 2010. Incorporating the Water Footprint and Virtual Water into Policy: Reflections from the Mancha Occidental Region, Spain. Water Resources Management 24, 941-958.

Allen, T. 1998. Watersheds and problemsheds: Explaining the absence of armed conflict over water in the Middle East. Middle East, 2(1), 50. 
Ansoff, H.I. 1984. Implanting Strategic Management. Edgewood Cliffs, NJ: Prentice-Hall.

Babin, D., Bertrand, A., Weber, J., Antona, M. 1999. Patrimonial mediation and management subsidiarity: managing pluralism for sustainable forestry and rural development. Pluralism and sustainable forestry and rural development. FAO-IUFRO-Cirad, Rome, pp. 277-303.

Bache, I. and Flinders, M. (eds). 2004. Multi-level governance. Oxford University Press, Oxford.

Barreteau, O., Abrami, G., Cernesson, F., Ducrot, R., Garin, P., Le Goulven, P., Maurel, P., Richard-Ferroudji, A., Souchère, V., Werey, C. 2010. Cities and their "water socio-footprint": a dynamic socio-technical network. Cities of the Future, Cambridge, MA.

Barreteau, O., Abrami, G., Daré, W., Du Toit, D., Ferrand, N., Garin, P., Souchère, V., Popova, A., Werey, C. 2012. Collaborative Modelling as a Boundary Institution to Handle Institutional Complexities in Water Management. In: Karl, H.A., Scarlett, L., Vargas-Moreno, J.C., Flaxman, M. (eds), Restoring Lands - Coordinating Science, Politics and Action. Complexities of Climate and Governance. Springer, pp. 109-127.

Berkes, F. 2002. "Cross-Scale Institutional Linkages: Perspectives from the Bottom Up." In: The Drama of the Commons, eds. Elinor Ostrom, Thomas Dietz, Nives Dolsak, Paul C. Stern, Susan Stonich, and Elke U. Weber. Washington, DC: National Academy Press, 293-322.

Bergström, S. and Graham, L. 1998. On the scale problem in hydrological modelling. Journal of Hydrology, $211(1), 253-265$.

Binder, C.R., Hinkel, J., Bots, P.W.G. and Pahl-Wostl, C. 2013. Comparison of frameworks for analyzing socialecological systems. Ecology and Society 18(4): 26. http://dx.doi.org/10.5751/ES-05551-180426

Brenner, N. 2001. The limits to scale? Methodological reflections on scalar structuration, Progress in Human Geography 25(4) pp. 591-614.

Budds, J. 2009. Contested H2O: Science, policy and politics in water resources management in Chile. Geoforum, 40(3), 418-430. 
Buizer, M., Arts, B. and Kok, K. 2011. Governance, scale and the environment: the importance of recognizing knowledge claims in transdisciplinary arenas. Ecology and society, 16(1): 21.

http://www.ecologyandsociety.org/vol16/iss1/art21/

Buleon, P., Di Meo, G. 2005. L'espace social : lecture géographique des sociétés. Armand Colin.

Carey, J.M., Zilberman, D. 2002. A Model of Investment under Uncertainty: Modern Irrigation Technology and Emerging Markets in Water. American Journal of Agricultural Economics 84, 171-183.

Carpenter, S.R., Kitchell, J.F. 1987. The temporal scale of variance in limnetic primary production. Am. Nat. 129, $417-433$.

Cash, D.W., Adger, W.N., Berkes, F., Garden, P., Lebel, L., Olsson, P., Pritchard, L. and Young, O. 2006. Scale and cross-scale dynamics: governance and information in a multilevel world. Ecology and Society 11(2): 8.

http://www.ecologyandsociety.org/vol11/iss2/art8/

Cohen, A. 2011. From Water to Watershed: an Analysis of Rescaled Water Governance In Canada, PhD Thesis, University of British Columbia, Vancouver.

Coleman, J.S. 1990. Foundations of Social Theory. Harvard University Press, Cambridge, MA, pp. 993.

Conca, K. 2006. Governing water. Contentious transnational politics and global institution building. Cambridge, MA/ London: MIT Press.

Cumming, G.S., Cumming, D.H.M. and Redman, C.L. 2006. Scale mismatches in social-ecological systems: causes, consequences, and solutions. Ecology and Society 11(1): 14.

http://www.ecologyandsociety.org/vol11/iss1/art14/

Daly, H.E. 1992. Allocation, distribution, and scale: toward an economics that is efficient, just, and sustainable. Ecol. Econ. 6, 185-193.

Dandy, G.C., Warner, R.F., Daniell, T.M. and Walker, D. 2007. Planning and Design of Engineering Systems: Revised Edition. Abingdon, UK: Taylor \& Francis Ltd. 
Daniell, K.A. 2012. Co-engineering and participatory water management: organisational challenges for water governance, UNESCO International Hydrology Series, Cambridge University Press, London.

Daniell, K.A., Máñez Costa, M.A., Ferrand, N., Kingsborough, A.B., Coad, P., Ribarova, I.S. 2011. Aiding multi-level decision-making processes for climate change mitigation and adaptation, Regional Environmental Change,

Vol.11, No.2, pp. 243-258. DOI: 10.1007/s10113-010-0162-0

Dasgupta, P. 1997. Notes on Slow and Fast Variables in Economics. Notes for the Resilliane Network, University of Florida, Department of Zoology, Gainesville.

De Blaeij, A. T., Polman, N. and Reinhard, S. 2011. Economic governance to expand commercial wetlands: withinand cross-scale challenges. Ecology and Society 16(1): 33. http://www. ecologyandsociety.org/vol16/iss1/art33/

Dinar, A., Rosegrant, M. W. and Meinzen-Dick, R. S. 1997. Water allocation mechanisms: principles and examples (No. 1779). World Bank Publications.

Dovers, S. 2010. Embedded scales: interdisciplinary and institutional issues. In: Brown, V.A., Harris, J.A. and Russell, J.Y. (eds), Tackling wicked problems through the transdisciplinary imagination, London, UK: Earthscan, pp.182-192.

Downs, P. W., Gregory, K. J. and Brookes, A. 1991. How integrated is river basin management? Environmental management, 15(3), 299-309.

Esty, D.C. 2006. Good Governance at the Supranational Scale: Globalizing Administrative Law, Yale Law Journal, $1490-1562$.

Ferrand, N., Hassenforder, E., Ducrot, R., Barreteau, O., Abrami, G. 2013. How agency models inspire large scale participatory planning and its evaluation. 20th International Congress on Modelling and Simulation, Adelaïde, Australia.

Foerster, A. 2011. Developing purposeful and adaptive institutions for effective environmental water governance. Water resources management, 25(15), 4005-4018. 
Folke, C, Pritchard, L., Berkes, F., Colding, J. and Svedin, U. 1998. The problem of fit between ecosystems and institutions. IHDP Working Paper No. 2. International Human Dimensions Program on Global Environmental Change, Bonn, Germany, http://www.ihdp.uni-bonn.de/html/publications/workingpaper/wp02m.htm

Folke, C., Pritchard, L., Berkes, F., Colding, J. and Svedin, U. 2007. The problem of fit between ecosystems and institutions: ten years later. Ecology and Society 12(1): 30. [online] URL:

http://www.ecologyandsociety.org/vol12/iss1/art30/

Fuss, M., McFadden, D. 1978. Production economics: a dual approach to theory and applications, North-Holland Publishing Company, Amsterdam.

Garmestani, A.S. and Benson, M.H. 2013. A framework for resilience-based governance of social-ecological systems. Ecology and Society 18(1): 9. http://dx.doi.org/10.5751/ES-05180-180109

Geels, F.W., Schot, J. 2007. Typology of sociotechnical transition pathways, Research Policy, 36, 399-417.

Gibson, C.C., Ostrom, E., Ahn, T.K. 2000. The concept of scale and the human dimensions of global change: a survey, Ecological Economics, 32: 217-239.

GWP - Global Water Partnership. 2000. Integrated water resource management. TAC Background papers, No. 4, Stockholm, Sweden.

Gouvernement du Québec. 2002. Water. Our Life. Our Future. Québec Water Policy.

http://www.mddep.gouv.qc.ca/eau/politique/policy.pdf.

Gunderson, L.H., Holling, C.S. (eds). 2002. Panarchy: understanding transformations in human and natural systems. Washington, DC: Island Press.

Harris, L.M. and Alatout, S. 2010. Negotiating Hydro Scales, Forging States: Comparison of the Upper Tigris/Euphrates and Jordan River Basins. Political Geography 29: 148-156.

Harvey, D. 1969. Explanation in Geography. St. Martin's Press, New York, pp. 521.

Heikkila, T., Schlager, E. and Davis, M.W. 2011. The Role of Cross-Scale Institutional Linkages in Common Pool Resource Management: Assessing Interstate River Compacts. Policy Studies Journal, 39(1), 121-145. 
Henry, C. 1974. Investment Decisions Under Uncertainty: The "Irreversibility Effect". The American Economic Review 64, 1006-1012.

Hodge, I. 1984. Uncertainty, Irreversibility and the Loss of Agricultural Land. Journal of Agricultural Economics 35, 191-202.

Hoppe, R. 2010. From "knowledge use" towards "boundary work": sketch of an emerging new agenda for inquiry into science-policy interaction. In: in't Veld, R. (ed.), Knowledge Democracy. Springer, pp. 169-186.

Jeffrey, P. and Gearey, M. 2006. Integrated water resources management: lost on the road from ambition to realisation? Water Science \& Technology, 53(1), 1-8

Klemes, V. 1983. Conceptualization and scale in hydrology. Journal of hydrology, 65(1), 1-23.

Krugman, P. 1986. Industrial Organization and International Trade. Working Paper no. 1957. National Bureau of Economic Research, Cambridge, MA.

Le Page, C., Abrami, G., Barreteau, O., Becu, N., Bommel, P., Botta, A., Dray, A., Monteil, C., Souchère, V. 2011. Models for sharing representations. In: Etienne, M. (ed.), Companion Modelling. A participatory approach to support sustainable development. QUAE, Versailles, France, pp. 69-96.

Levin, S. 1992. The problem of pattern and scale in ecology. Ecology, 73, 1943-1967.

Linton, J. and Budds, J. 2014. The hydrosocial cycle: Defining and mobilizing a relational-dialectical approach to water. Geoforum, 57, 170-180.

Loucks, D.P. 1998. Watershed planning: Changing issues, processes and expectations. Water Resources Update, $111,38-45$

Lowry, G.K., White, A.T. and Christie, P. 2009. Scaling Up to Networks of Marine Protected Areas in the Philippines: Biophysical, Legal, Institutional, and Social Considerations, Coastal Management, 37:274-290.

Lubell, M. 2013. Governing institutional complexity: The ecology of games framework. Policy Studies Journal, 41(3), 537-559. 
Manson, S.M. 2008. Does scale exist? An epistemological scale continuum for complex human-environment systems. Geoforum, 39(2), 776-788.

Marshall, G.R. 2008. Nesting, Subsidiarity, and Community-Based Environmental Governance beyond the Local Level, International Journal of the Commons, 2(1), pp. 75-97.

Meentemeyer, V. 1989. Geographical perspectives of space, time, and scale. Landscape Ecol. 3 (3/4), $163-173$.

Merz, R., Parajka, J. and Blöschl, G. 2009. Scale effects in conceptual hydrological modeling. Water resources research, 45(9). DOI: 10.1029/2009WR007872

Mintzberg, H. 1989. Mintzberg on Management. Inside Our Strange World of Organisations. New York: Free Press.

Mollinga, P.P., Meinzen-Dick, R.S., Merrey, D.J. 2007. Politics, plurality and problemsheds: A strategic approach for reform of agricultural water resources management. Development Policy Review, 25(6), 699-719.

Moss, T., Medd, W., Guy, S. and Marvin, S. 2009. Organising water: The hidden role of intermediary work. Water Alternatives 2(1): 16-33.

Moss, T. and Newig, J. 2010. Multilevel water governance and problems of scale: Setting the stage for a broader debate. Environmental Management, 46(1), 1-6.

Nelson, M.C., Kintigh, K., Abbott, D.R., Anderies, J.M. 2010. The Cross-scale Interplay between Social and Biophysical Context and the Vulnerability of Irrigation-dependent Societies: Archaeology's Longterm Perspective. Ecology and Society 15, 31.

Norman, E.S., Bakker, K. and Cook, C. 2012. Introduction to the themed section: Water governance and the politics of scale. Water Alternatives 5(1): 52-61.

Ostrom, E. 1990. Governing the commons: The evolution of institutions for collective action. Cambridge University Press, Cambridge.

Ostrom, E. 1999. Coping with Tragedies of the Commons, Annual Review of Political Science, 2, 493-535.

Ostrom, E. 2005. Understanding Institutional Diversity, Princeton University Press, New Jersey. 
Ostrom, E., Gardner, R., Walker, J.M. 1994. Rules, Games, and Common-Pool Resources. University of Michigan Press, Ann Arbor.

Ostrom, V., Tiebout, C.M., Warren, R. 1961. The organization of government in metropolitan areas: a theoretical inquiry. Amer. Pol. Sci. Rev. 55 (4), 831-842.

Pahl-Wostl, C. 2008. Climate Change - a Global Challenge for Water Governance. ExpoZaragoza 2008. http://www.zaragoza.es/contenidos/medioambiente/cajaAzul/18S6-P3-Pahl\%20WostlACC.pdf [accessed $12 / 05 / 14]$

Pahl-Wostl, C., Holtz, G., Kastens, B., Knieper, C. 2010. Analyzing complex water governance regimes: the Management and Transition Framework, Environmental Science \& Policy, 13: 571-581.

Peterson, D., Parker, V.T. 1998. Ecological scale: Theory and applications, New York: Columbia University Press.

Rhodes, R.A.W. 1996. The New Governance: Governing without Government. Political Studies, 44: 652-667. doi: 10.1111/j.1467-9248.1996.tb01747.x

Ridoutt, B.G., Pfister, S. 2010. A revised approach to water footprinting to make transparent the impacts of consumption and production on global freshwater scarcity. Global Environmental Change, 20, 113-120.

Samuelson, P.A. 1973. A diagrammatic exposition of a theory of public expenditure. Rev. Econ. Stat. 37, 360366.

Sayre, N.F. 2005. Ecological and geographical scale: parallels and potential for integration, Progress in Human Geography, 29(3), 276-290

Sivapalan, M., Grayson, R., Woods, R. 2004. Scale and scaling in hydrology. Hydrological Processes, 18(8): 13691371.

Smith, N. 1992. Geography, difference and the politics of scale. In: Postmodernism and the social sciences, eds. J. Doherty, E. Graham, and M. Malek, 57-79. New York: St. Martin's Press. 
Sneddon, C. 2002. Water Conflicts and River Basins: The Contradictions of Comanagement and Scale in

Northeast Thailand. Society \& Natural Resources: An International Journal, 15(8), 725-741, DOI:

$10.1080 / 08941920290069317$

Sneddon, C., Harris, L., Dimitrov, R. and Özesmi, U. 2002. Contested waters: Conflict, scale, and sustainability in aquatic socioecological systems. Society \& Natural Resources, 15(8), 663-675.

Snellen, W.B. and Schrevel, A. 2004. IWRM: for sustainable use of water 50 years of international experience with the concept of integrated water management. In FAO/Netherlands Conference on Water for Food and Ecosystems. http://www.colinmayfield.com/WHCourse/IWRM\%20Documents/IWRM_Backgroundonepage.pdf Squires, V.R., Milner, H., Daniell, K.A. (eds). 2014. River Basin Management in the 21st Century: People and Place, Science Publishers (CRC Press), Boca Raton.

Starr, G.C. 2004. Assessing temporal stability and spatial variability of soil water patterns with implications for precision water management. Agricultural Water Management, 72, 223-243.

Steinberg, P.E., Clark, G.E. 1999. Troubled water? Acquiescence, conflict and the politics of place in watershed management. Political Geography 18, 477-508.

Swyngedouw, E. 1997. Neither global nor local: "Glocalization" and the politics of scale. In: Spaces of globalization: Reasserting the power of the local, ed. K. Cox, 137-166. New York: Guilford Press.

Swyngedouw, E. 2004. Globalisation or ‘Glocalisation’? Networks, Territories and Rescaling. Cambridge Review of International Affairs, 17(1): 26-48.

Swyngedouw, E. 2010. Place, nature and the question of scale. Interrogating the Production of Nature. BerlinDiscussion Paper 5. Brandenburgische Akademie der Wissenschaften, Berlin.

Syme, G.J., Reddy, V.R., Pavelic, P., Croke, B., Ranjan, R. 2012. Confronting scale in watershed development in India, Hydrogeology Journal (2012) 20: 985-993, DOI 10.1007/s10040-011-0824-0 
Termeer, C. J. A. M., Dewulf, A. and van Lieshout, M. 2010. Disentangling scale approaches in governance research: comparing monocentric, multilevel, and adaptive governance. Ecology and Society 15 (4): 29. [online] URL: http://www.ecologyandsociety.org/vol15/iss4/art29/

Tilly, C. 1984. Big Structures, Large Processes, Huge Comparisons. Russell Sage Foundation, New York, pp. 176.

Turner, M.G., Dale, V.H. and Gardner, R.H. 1989: Predicting across scales: theory development and testing. Landscape Ecology 3, 245-52.

Walker, B., Gunderson, L.H., Kinzig, A.P., Folke, C., Carpenter, S.R., Schulz, L. 2006. A Handful of Heuristics and Some Propositions for Understanding Resilience in Social-Ecological Systems. Ecology and Society 11, http://www.ecologyandsociety.org/vol11/iss11/art13/.

Wilson, J., Low, B., Costanza, R. and Ostrom, E. 1999. Scale misperceptions and the spatial dynamics of a socialecological system. Ecological Economics, 31(2), 243-257.

Veldkamp, A., Polman, N., Reinhard, S. and Slingerland, M. 2011. From scaling to governance of the land system: bridging ecological and economic perspectives. Ecology and Society 16(1): 1. [online] URL: http:// www.ecologyandsociety.org/vol16/iss1/art1/

Young, O. 2002a. The institutional dimensions of environmental change: fit, interplay, and scale. MIT Press, Cambridge, Massachusetts, USA.

Young, O. 2002b. “Institutional Interplay: The Environmental Consequences of Cross-Scale Interactions.” In: The Drama of the Commons, eds. Elinor Ostrom, Thomas Dietz, Nives Dolsak, Paul C. Stern, Susan Stonich, and Elke U. Weber. Washington, DC: National Academy Press, 263-292. 